\title{
To see and not be seen: the visibility of predator and prey with respect to feeding behaviour
}

\author{
Helmut Thetmeyer *, Uwe Kils
}

Institut für Meereskunde an der Universität Kiel, Abteilung Fischereibiologie, Düsternbrooker Weg 20, D-24105 Kiel, Germany

\begin{abstract}
The visibility of herring Clupea harengus and mysids Praunus flexuosus was studied in the shallow water of the Kiel Fjord (Baltic Sea). The apparent brightness contrast of the predator (herring) and its prey (mysid) were measured from various visual angles with an underwater video system. The camera looked at the prey from the predator's point of view and vice versa. During a head-on encounter, the contrast of the prey against the ocean background was very poor. With increasing visual angles (relative to a horizontal plane), the visibility of the prey improved. The predator was most visible from below, but was excellently camouflaged when observed from above or from a horizontal line of vision. When the herring was located 30 to $90^{\circ}$ below the mysid, the prey was fairly visible to the predator but the predator was nearly invisible to the prey. By incorporating these ocean optics and taking into account the limits of the maneuvering potential of cruising herring, an optimal attack angle can be postulated: at oblique predator-prey configurations between 30 and $60^{\circ}$, herring are still capable of modulating their normal cruising to an upward directed position while the preconditions of a successful attack - to see and not to be seen - are fulfilled. In Kiel Aquarium, adult herring attacked mysids from an average angle of $48^{\circ}$ from below. In situ measurements from inside a feeding school of juvenile herring showed a mean attack angle of $43^{\circ}$
\end{abstract}

KEY WORDS: Feeding behaviour - Visibility Visual contrast - Camouflage - Predator-prey - Clupea harengus P Praunus flexuosus - Mysidacea

\section{INTRODUCTION}

Herring Clupea harengus attack their prey predominantly from below (Battle et al. 1936, Johnson 1939a, Blaxter \& Holliday 1958, Rosenthal 1969, Rosenthal \& Hempel 1970, Gibson \& Ezzi 1985, 1990, Batty et al. 1990). Morphological adaptations, such as the superior mouth position and the upper-fore directed visual axis, confirm the ecological importance of the observed behaviour in the pelagic environment (Tamura 1957, Tamura \& Wisby 1963, Blaxter \& Jones 1967, Lythgoe 1979).

Like many other pelagic fish, herring detect their prey mainly visually (Battle et al. 1936, Johnson 1939b, Bhattacharyya 1957, Blaxter \& Holliday 1958, Blaxter 1964, 1980, Batty et al. 1990). Therefore, prey organisms can improve their chances of survival by reducing

•E-mail: hthetmeyer@ifm.uni-kiel.d400.de their visibility (Schnack 1972, Zaret 1972, Zaret \& Kerfoot 1975, Eggers 1977, Gerritsen \& Strickler 1977. Kettle \& O'Brien 1978, O'Brien 1979, Kerfoot et al. 1980, Stenson 1980, Flinkman et al. 1988). Thus, there will be a selective pressure favouring the camouflage of prey. On the other hand, many food organisms of the herring, like gobies, euphausiids, and mysids, have well-developed eyes, too. Even copepods react to shading (Strickler 1970). If a herring can more closely approach an alert and evasive prey before triggering an escape reaction, its feeding success will increase (Dremner et al. 1978, Drenner \& McComas 1980, Blaxter \& Fuiman 1990, Rademacher 1993). Hence, evolution will also favour the camouflage of the predator.

Visual perceptibility is determined by differences in luminance and colour between an object and its background (Duntley 1962, Rosenthal \& Hempel 1970, Jerlov 1976, Vinyard \& O'Brien 1976, Anthony 1981). Hester (1968) argues that for aquatic environments the brightness contrast is predominant. Because of the 
very special light conditions in the ocean, like the strong gradient in background luminance, the scattering of incident light, or the distinct amgular radiance distribution (Duntley 1963, Lythgoe 1979, Loew \& McFarland 1990), contrast measurements should preferably be conducted in situ.

In this study, we quantified the brightness contrast of herring and mysids from various directions under natural light conditions in the sea. We examined whether an optimal attack angle can be derived from the optical properties of predator and prey. Attack angles of feeding herring were measured in aquaria and in situ and compared with the values expected from ocean optics.

\section{MATERIALS AND METHODS}

Contrast measurements. As an index of visibility the apparent brightness contrast of herring and mysids was determined in the sea. Apparent contrast $\left(C_{r}\right)$ is the difference between object luminance $\left(L_{r}\right)$ and background luminance $\left(L_{\mathrm{b} r}\right)$ relative to background luminance at the distance $r$ (Jerlov 1976).

$$
C_{r}=\frac{L_{r}-L_{b r}}{L_{b r}}
$$

Objects darker than the background have negative contrasts from - 1 to zero, brighter ones positive values from zero to infinity.

The specimens used for the contrast measurements were caught at the experimental site in the Kiel Fjord (Baltic Sea, Germany), near the locks of the Kiel Canal in September 1988. The juvenile herring Clupea harengus were caught using a lift net with a hard codend. A dip net was used to catch mysids Praunus flexuosus. The Secchi depth was equal to the water depth, which was $5 \mathrm{~m}$. The silty bottom was covered with kelp and red algae.

A herring (total length $=67 \mathrm{~mm}$ ) was killed with quinaldine and tethered to a thin wire with cyanoacrylate. A mysid (length from tip of rostrum to end of telson $=23 \mathrm{~mm}$ ) was tethered alive. As controls, models of similar size and shape were carved from wood and painted black or white. The wire with the tethered animals or controls was fixed to a tripod at a depth of $2.5 \mathrm{~m}$. A diver turned a CCD camera in steps of $30^{\circ}$ around the objects (fjeld size: $214 \times 141 \mathrm{~mm}$ for herring, $60 \times 39 \mathrm{~mm}$ for mysid; object distance: $520 \mathrm{~mm}$ for herring, $400 \mathrm{~mm}$ for mysid). The visual angles of predator and prey were measured against a horizontal plane. The angles describing the lines of sight of the predator and prey were defined as $\alpha$ and $\beta$ respectively (see Fig. 1). The values of $\alpha$ and $\beta$ are equal for each predator-prey configuration. The video signals were

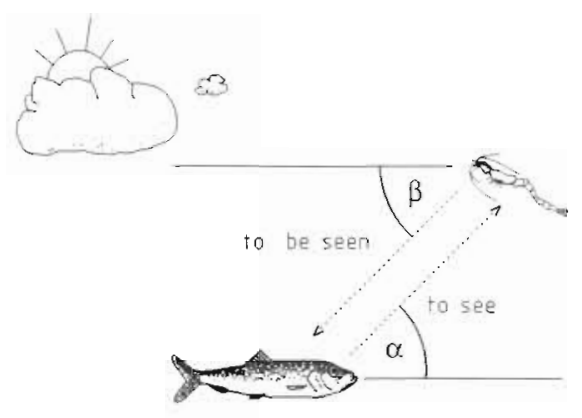

Fig. 1. Sketch of a typical predator-prey configuration with definitions of angles. During the experiments, the sky was overcast. The position of the sun is indicated

transferred to the floating laboratory 'ATOLL' for recording and evaluation (Kils 1986). A spot-sensor registered the background luminance for calibration of the camera signals (aperture angle $=13^{\circ}$ ). During the measurements, the sky was overcast (illuminance was about $4000 \mathrm{~lx}$ at $2.5 \mathrm{~m}$ ); the position of the sun is indicated in Fig. 1

The video signals were digitized $(320 \times 200$ pixels, 16 grey levels) and calibrated with a continuous grey scale (Göttinger Farbfilterwerke). Figs. 2 \& 3 show print-outs of digitized images of the herring, the mysid, and the models. Small angular deviations of the objects due to microturbulences caused very little variance between sequential measurements in the mysid, but some in the herring For this reason, 1 image was evaluated for every visual angle for the mysid and the mean of 3 different images was used for the herring.

To compensate for vignetting, to analyse the distribution of grey levels in areas of interest, and to assign relative luminance values to these grey levels, the computer program dynIMAGE was developed (Thetmeyer 1989, Kils 1992). Frequency distributions of grey levels were determined from the objects and from the background beside them (see Fig. 4). The median, the first and ninth deciles, and the extremes of the object, and the median grey level of the background were converted into relative luminance values. Using these values, contrast was determined and plotted in Figs. 5 to 7 as bars and lines over the different angles of view. When contrast was calculated from a relative luminance corresponding to the brightest grey level, the respective marker was extended by dotted lines (a single line for the maximum and double lines for the deciles). This symbolizes the fact that the contrast was out of range (the 16th grey level represents an openend class) and the plotted value should be interpreted as a minimum.

Feeding behaviour. About 270 adult herring, caught by means of a fish trap in the Kiel Canal., were kept in a circular tank (depth $=105 \mathrm{~cm}$, volume $=10$ to $\left.11 \mathrm{~m}^{3}\right)$ 


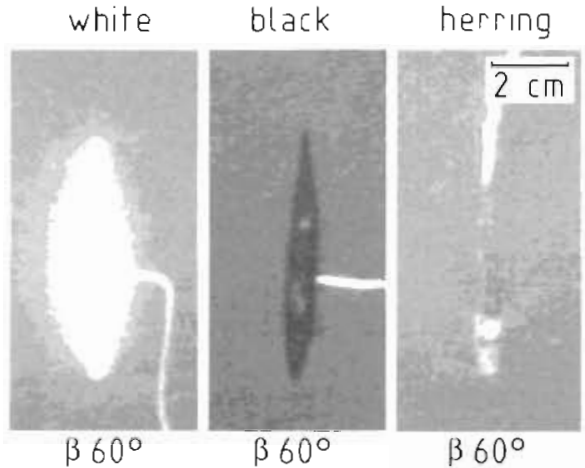

Fig. 2. Prey's view of predator (Clupea harengus) in the oblique constellation of Fig. 1 ( $\beta=60^{\circ}$ from above): white control, black control, and tethered herring are seen from a distance of $520 \mathrm{~mm}$. The digital image consists of 16 grey levels, shown in the grey scale at the bottom of Fig. 4. Recordings from 12 September 1988, 15:00 to $17: 00 \mathrm{~h}$, sky overcast, illumination $3900 \mathrm{~lx}$ in $2.5 \mathrm{~m}$
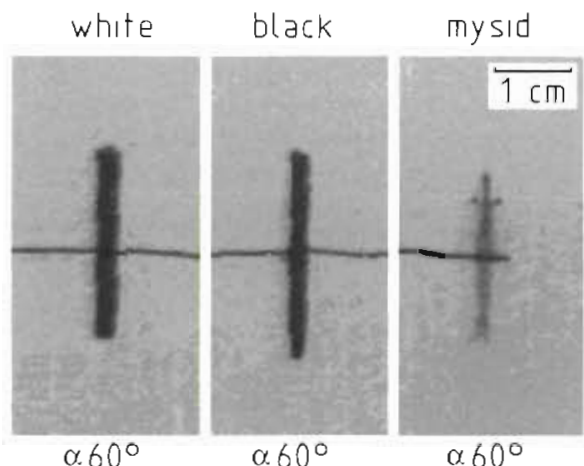

Fig. 3. Predator's view of prey (Praunus flexuosus) in the oblique constellation of Fig. 1 ( $\alpha=60^{\circ}$ from below): white control, black control, and tethered mysid are seen from a distance of $400 \mathrm{~mm}$. The digital image consists of 16 grey levels, shown in the grey scale at the bottom of Fig. 4. Recordings from 20 September $1988,13: 20$ to $13: 50 \mathrm{~h}$, sky overcast, illumination $4500 \mathrm{~lx}$ in $2.5 \mathrm{~m}$

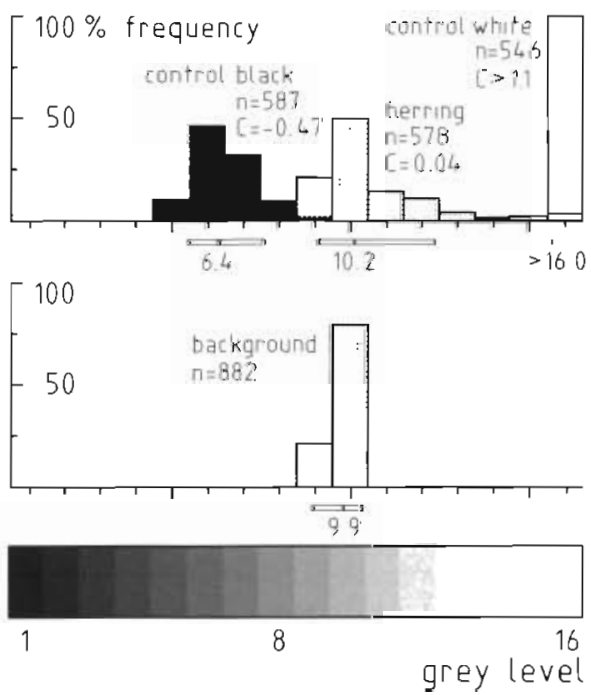

of the Kiel Aquarium and supplied with water from the Kiel Fjord. Total length ranged from 228 to $301 \mathrm{~mm}$, with a mean of $274 \mathrm{~mm}(\mathrm{SD}=17 \mathrm{~mm}, \mathrm{n}=57)$. Two fluorescent lamps and 2 opaque skylights illuminated the water surface (about $8300 \mathrm{~lx}$ ). After an acclimation time of more than $6 \mathrm{mo}$, the feeding experiments were conducted in October 1988.

The herring readily accepted the offered prey organisms, while the normal food ration was kept low $(1 \%$ body weight $\mathrm{d}^{-1}$ Antarctic krill Euphausia superba). Mysids were released from an open vessel of the bottom and allowed to swim up into the herring school, while the feeding behaviour was recorded by video ( 50 frames $\mathrm{s}^{-1}$ ) from a lateral aspect. Swimming speed [body lengths (bl) $\left.\mathrm{s}^{-1}\right]$ and swimming/attack angle were evaluated from digitized video sequences with the dynIMAGE-software The attack angle $\delta$ was defined as the angle between water surface and fish during capture (for curved fish, the middle line of the head was used).

Juvenile herring were investigated in situ at their nursery grounds in the inner part of the Kiel Fjord off Kiel-Holtenau $\left(54^{\circ} 22^{\prime} 00^{\prime \prime} \mathrm{N}, 1^{\circ} 08^{\prime} 97^{\prime \prime}\right.$ E). At this location, the floating laboratory 'ATOLL' was anchored (a $27 \mathrm{~m}$ doughnut-shaped structure; Kils 1986). On 24 July, 17:40 to $18: 25 \mathrm{~h}$, the swimming dynamics of herring (mean bl $39 \mathrm{~mm}, \mathrm{SD}=11 \mathrm{~mm}, \mathrm{n}=30$ ) were measured with a '3D-ecoSCOPE', a miniaturized, camouflaged ROV (remotely operated vehicle) with a thin endoscope which protruded into a school of herring feeding on copepods, allowing for an imaging of predator and prey (Kils 1992). Environmental conditions: clear sky, water temperature $24^{\circ} \mathrm{C}$, small surface waves; yellow perches, smelts, sandeels and terns were feeding on the herring school. With the dyniMAGE-software, microturbulences and system-swaying were compensated for and the attack angles evaluated.

\section{RESULTS}

\section{Contrast measurements}

Figs. 2 \& 3 show print-outs of video images recorded from the point of view of the prey looking at the predator and vice versa (arrangement as in Fig 1;

Fig. 4. Frequency distributions of grey levels in distinct areas of Fig. 2. The upper graph shows the grey levels of the 3 objects (herring and controls). n: number of evaluated pixels; $C$ : corresponding contrast. The frequency distribution of the background (lower graph) corresponds to the picture of the herring. The digital image consists of 16 grey levels, shown in the grey scale. The boxes below the abscissa show the median with the first and ninth decile 


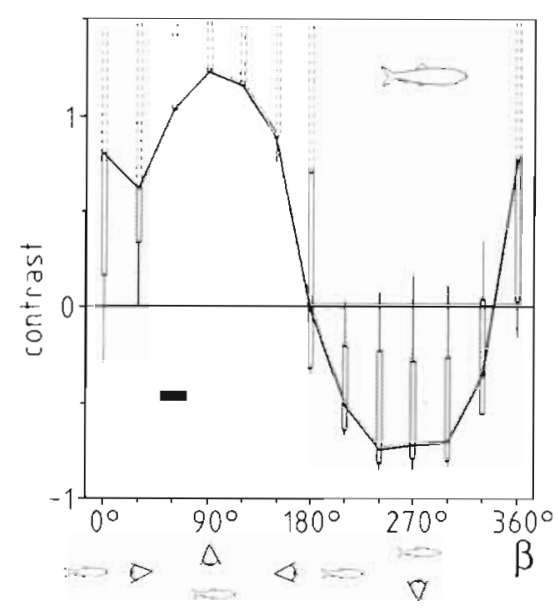

Fig. 5. Contrast of the white control from different prey aspects ( $\beta$-angles). Some configurations are symbolized by icons. The median contrast values are connected with a solid line. The area between the line and the $x$-axis is shaded. The first and ninth deciles and the extreme contrast values are shown as bars and vertical lines. The extension of markers with dotted lines indicates that the measuring interval was exceeded and the true contrast value could be considerably higher than the given lower limit. Recordings from the 12 September $1988,15: 00$ to $17: 00 \mathrm{~h}$, sky overcast, illumination $3900 \mathrm{~lx}$ in $2.5 \mathrm{~m}$, camera distance $520 \mathrm{~mm}$. For $\beta=60^{\circ}$ the contrast value of the black control is indicated with a black square

$\alpha=\beta=60^{\circ}$ ). Beside the herring or mysid specimen, a black and a white control are shown for comparison. Each image consists of 16 grey levels as displayed in the grey scale below Fig. 4.

The white model in Fig. 2 appears bright and is surrounded by a 'glow'. The black model is less striking, but since it is considerably darker than the background it is also easily perceptible. Beside the herring models the tethering wire is visible. In comparison to the models, the contrast between herring and the background is extremely low. The most conspicuous part of the fish is the head with a bright spot behind the eyes; the tethering wire shows up white in the caudal area of the fish (upper part of the picture).

From the predator's point of view (Fig. 3), the tethering wires and both the black and white controls show up very dark. Only in the case of the translucent mysid is there noticably less contrast. Nevertheless, the whole crustacean is fairly visible. The darkest parts of its body are the intensely pigmented eyes.

In Fig. 4 the frequency distributions of grey levels are compared between herring (shaded columns in the upper part) and the background (lower part). The 578 pixels evaluated within the herring had a median of 10.2 , which is very close to the corresponding background value of 9.9. The white control reached the upper end of the range. The black control is represented by the grey levels 5 to 9 with a median of 6.4 .

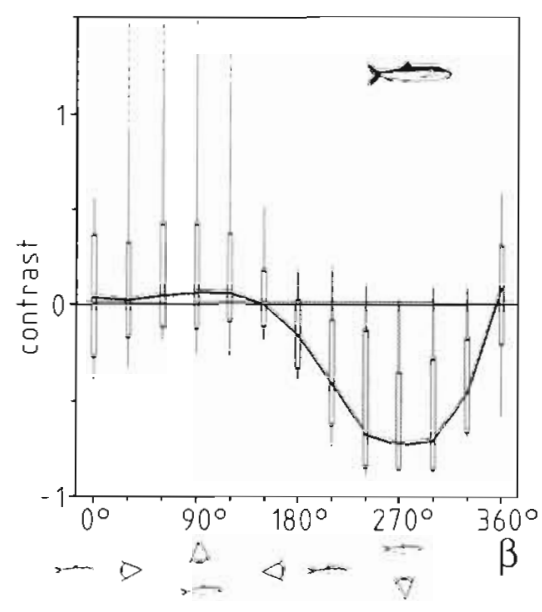

Fig. 6. Contrast of the herring from different prey aspects ( $\beta$ angles). Recordings from 12 September $1988,15: 00$ to $17: 00 \mathrm{~h}$, sky overcast, illumination $3900 \mathrm{~lx}$ in $2.5 \mathrm{~m}$, camera distance $520 \mathrm{~mm}$. See Fig. 5 for further explanations

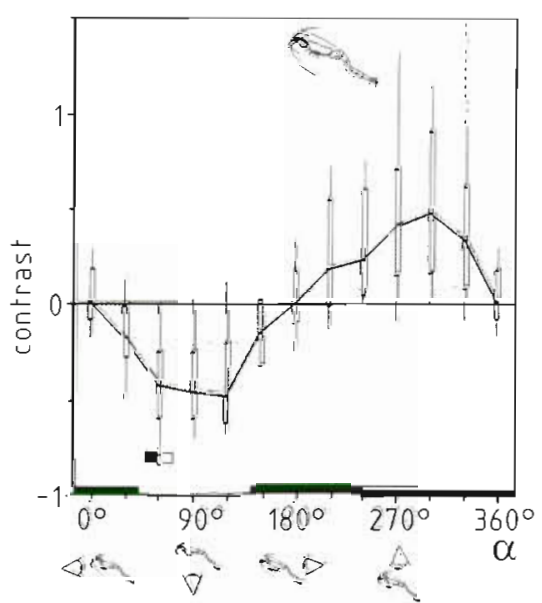

Fig. 7. Contrast of the mysid from different predator aspects $(\alpha$-angles). Recordings from 20 September 1988, 13:20 to 13:50 h, sky overcast, illumination $4500 \mathrm{~lx}$ in $2.5 \mathrm{~m}$, camera distance $400 \mathrm{~mm}$. See Fig. 5 for further explanations. For $\alpha=$ $60^{\circ}$ the contrast values of the black and white controls are symbolized by a black and white square, respectively. Snell's window is indicated by the gap in the bar above the abscissa

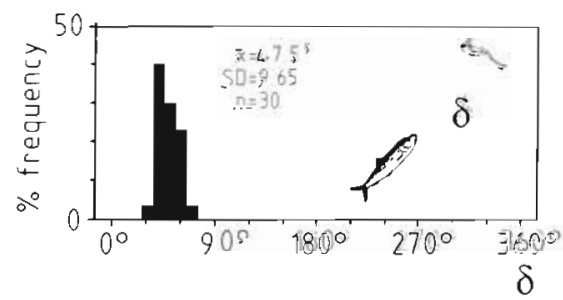

Fig. 8. Clupea harengus and Praunus flexuosus. Frequency distribution of the attack angle of adult herring feeding on mysids in aquaria. $\bar{x}$ : mean attack angle; SD: standard deviation; $\mathrm{n}$ : number of observations 
After converting the medians into relative luminance values, a contrast value of 0.04 resulted for the herring. From the medians of the controls, much higher contrast values were calculated: $C_{r}>1.1$ for the white control, $C_{r}=-0.47$ for the black control.

The contrast values varied considerably with the angle of view, as summarized for the white control in Fig. 5, the herring in Fig. 6, and the mysid in Fig. 7. For all aspects from above, the white control was very conspicuous with contrast values higher than 0.6 (Fig. 5). The black square represents the contrast value of the black control for $\beta=60^{\circ}$. The herring was much better camouflaged in this range (Fig. 6). From the horizontal front aspect $\left(\beta=0^{\circ}\right)$ and all above aspects up to $150^{\circ}$, the median contrast values were smaller than 0.07 . For the constellation sketched in Fig. $1\left(\beta=60^{\circ}\right)$ the contrast value was 0.04 . When observed from below, the herring was much more conspicuous: for $\beta=210$ to $330^{\circ}$ the median contrast value was between -0.40 and -0.73 . From below, the herring was as conspicuous as the white control. For prey swimming below the herring, the body of the fish is visible as a dark silhouette against the bright light of the sky.

For the mysid, a head-on view $\left(\alpha=0^{\circ}\right)$ yielded poor contrast (Fig. 7). When the camera descended below the mysid, its visibility increased. At $\alpha=60^{\circ}$ from below, the contrast value was -0.42 (corresponding to the image in Fig. 3). However, at this angle the black as well as the white controls showed up with much higher contrast (black and white squares). Looking downwards, the mysid appeared brighter than the background.

\section{Feeding behaviour}

Under normal conditions, the captive adult herring cruised in the circular basin at an average speed of 1.0 bl s-1 $(\mathrm{SD}=0.22, \mathrm{n}=20)$ and a swimming angle $\delta$ of $1^{\circ}$ relative to a horizontal plane $(\mathrm{SD}=7.5, \mathrm{n}=119 ; \delta$ as defined in Fig 8).

Mysids were almost exclusively attacked from below. The feeding act can be divided into a series of discrete components: (1) reduction of swimming speed; (2) orientation of the body axis towards the prey; (3) acceleration by powerful beatings of the caudal fin; (4) biting for the prey; (5) reduction of swimming speed by performing a $180^{\circ}$ turn; (6) swimming down to the former depth $_{i}$ and (7) joining the school by performing another $180^{\circ}$ turn, or introduction of another attack. In order for the herring to reintegrate itself into the school, some of the above-listed components could be modified or even omitted. Often, the mysid darted away a split second before the herring tried to catch it. Attacking herring accelerated to an average swimming speed of $3.5 \mathrm{bl} \mathrm{s}^{-1}(\mathrm{SD}=1.1, \mathrm{n}=20)$ with a maxi- mum of $5.6 \mathrm{bl} \mathrm{s}^{-1}$. The average attack angle $\delta$ was $47.5^{\circ}$ $(\mathrm{SD}=9.7, \mathrm{n}=30$, Fig. 8$)$.

When the juvenile herring encountered copepods in situ they switched to a very similar behavioural sequence, but the average attack angle $\delta\left(42.8^{\circ}\right.$, $\mathrm{SD}=10.9, \mathrm{n}=261$ ) was several degrees smaller. The difference between the 2 means was significant ( $U$ test, $\mathrm{p}<0.05$ ).

\section{DISCUSSION}

The visibility of planktonic prey is strongly affected by the angle between the prey and the approaching predator. For a cruising fish, a mysid swimming straight ahead is poorly visible prey (Fig. $7, \alpha=0$ or $180^{\circ}$ ). Mysids swimming above, as well as below, would be more visible to a foraging herring. Although mysids are quite transparent, those swimming below appear somewhat brighter against a dark sea-floor due to light scattered in their tissue. On shallow sandy grounds, there is more upwelling light than at the experimental site. Under such circumstances camouflage should be better. Mysids above the herring appear somewhat darker against the bright light of the sky due to absorbance at opaque parts of the body. Most conspicuous are the eyes, which have to be pigmented in order to function (Fig. 3) (Zaret 1972, Zaret \& Kerfoot 1975, Kislalioglu \& Gibson 1976, O'Brien 1979). In comparison with the opaque controls (both the black and the white control), the mysid is still hard to detect from below (Fig. 3). Another way to reduce silhouetting is avoidance of direct sunlight: normal diurnal light levels of $10^{3}$ to $10^{4} \mathrm{~lx}$ produce a negatively phototactic response in most mysid species, and diel vertical migrations are very common in mysids (Otterstrøm 1910, Mauchline 1980, Debus et al. 1992). Our results indicate that the transparency of mysids is an excellent strategy for staying invisible to horizontally scanning eyes and a moderately successful strategy for providing camouflage from upward or downward scanning eyes.

Herring beyond the larval stage lose transparency. The more complex the organism, the more difficult it would be to achieve overall body transparency (McFall-Ngai 1990). The camouflage of juvenile and adult herring is achieved by the dark pigmentation of the dorsum and the reflective layers of the lateral surfaces. Such silvery fish are only conspicuous when viewed from below (Fig. 6; 210 to $330^{\circ}$ ) (Denton \& Nicol 1965a, b, 1966). Some mesopelagic fish, cephalopods, and euphausiids compensate for this silhouetting by means of downwelling, biogenic light produced by the luminophores on their ventral sides (Clarke 1963, Hastings 1971, Young \& Roper 1976). 
However, herring is nearly perfectly disguised from above: for all aspects between 0 and $150^{\circ}$, the median contrast values were less than 0.07 (Fig. 6). As can be seen in Fig. 2, most body parts were nearly invisible. Only the outline of the head shows up. The white spot above the brain is presumably an artifact due to changes of the chromatophores after death. We did not observe such a white spot in live herring. Clupeids adapt their pigmentation to the sea floor and refuse to pass over mismatching ground (Breder 1959, Nicol 1961). In agreement with Denton \& Nicol. (1965a, b, 1966), these results show that herring have evolved an excellent strategy for staying invisible not only to horizontally scanning, but also to downward scanning eyes. When the herring is located 30 to $90^{\circ}$ below the mysid, the prey is fairly visible for the predator but the predator is nearly invisible to the prey. At $60^{\circ}$, the median contrast value for the herring was as small as 0.04 and the corresponding contrast value for the mysid was -0.42 . Human eyes can resolve contrasts down to 0.02 (Lythgoe 1971), goldfish Carassius auratus to 0.05 (Hester 1968), and cod Gadus morhua to about 0.02 (Anthony 1981).

Considering these physical aspects, and taking into account the limits of the maneuvering potential of fast cruising herring, an optimal attack angle can be postulated: at oblique predator-prey configurations between 30 and $60^{\circ}$, a herring is still capable of modulating its normal cruising into an upwardly directed attack, when the preconditions for successful prey capture to see and not to be seen - are fulfilled. The distribution of attack angles from adult herring feeding on mysids (mean $48^{\circ}$; Fig. 8) and many reports from the literature support this hypothesis.

For prey alerted by senses other than vision, a herring would still benefit from the enhanced contrast of particles in the upper front sector of the visual field. The in situ observations showed that juvenile herring attacked copepods from angles of around $43^{\circ}$ from below. Copepods have no well-developed visual sense, but they are captured by means of a strong change in angular momentum, too. From the energetic point of view, it would be much more economic for the predator to catch the prey with a minimum of change in angular momentum. Adult herring are able to catch copepods and other small prey organisms by filterfeeding at very high prey concentrations (Gibson \& Ezzi 1985, 1990, Thetmeyer 1989). Filter-feeding fish can swim horizontally, but they have a high energy demand due to the increased drag caused by the open mouth (Durbin et al. 1981).

Munk (1970), Lythgoe (1979) and Janssen (1981) point out another advantage of pelagic fish foraging in the upper front sector: close to the water surface just outside Snell's window $\left(41.4^{\circ}\right.$ to the horizontal) dark field illumination improves visibility. Indeed, Janssen (1981) found that blueback herring Alosa aestivalis exclusively attacked planktonic prey along trajectories 28 to $40^{\circ}$ to the horizontal. In all our measurements there is a bias towards overestimating the angle of attack because fish which do not swim exactly perpendicular to the camera's view will appear to attack at higher angles. Hence, the true mean is expected to be a few degrees lower. In Janssen's (1981) experiments with $A$. aestivalis, there was the same source of error, but during 60 observations he did not register a single attack inside Snell's window.

In our measurements on herring the edge of Snell's window was less sharply defined because of small waves on the sea surface and the artificial light conditions in our public aquarium. In addition to other factors (e.g. predator and prey species and size) this could explain the higher and more variable attack angles derived from our investigation. Differences in the light regime could also be the reason for the somewhat higher attack angles in the aquarium in comparison to the sea. However, this difference of only $5^{\circ}$ could easily be the result of systematic errors in measurement.

Since the fish attacked predominantly around the boundary of Snell's window, a better resolution in this angular range should be achieved in future contrast measurements. The measuring instruments should be calibrated according to the spectral sensitivity of the animals studied (Blaxter 1964). This study considers visual perception based on individual interactions between a single predator and a single prey. The effects of schooling have to be considered in future investigations on predator-prey perception. Can, for example, the feeding activity of a few individuals betray the presence of the rest of the school? In addition to the apparent brightness contrast which we investigated here, other visual properties like wavelength of radiation (including IR and UV), polarisation, patterns, size and motion contribute to predator-prey recognition (Protasov 1968, Lythgoe 1979, O'Brien 1979, Janssen 1982, and others). Therefore, more emphasis needs to be given to assessing the little-studied roles of ocean physics in feeding success, growth rates, reproductive output, and mortality rates including losses to predators (GLOBEC 1989).

Acknowledgements. We thank K. Able, R. S. Batty, J. H. S. Blaxter, U. Fiedler, P. Fischer, R. N. Gibson, J. Kinzer, J. E. Purcell, $\mathrm{K}$ Rademacher and $\mathrm{F}$. Thurow for comments on the manuscript. Atari, NeXT and Sony for their cooperation, the Volkswagen foundation for funding, the Deutsche Forschungsgemeinschaft (DFG) for support, as well as $\mathrm{H}$.- $\mathrm{H}$. Trekel, the Kiel Aquarium, Baudirektor H. Helms and the administration of Kiel Canal 


\section{LITERATURE CITED}

Anthony PD (1981) Visual contrast thresholds in the cod Gadus morhua L. J Fish Biol 19:87-103

Battle $\mathrm{HI}$, Huntsman AG, Jeffers AM, Jeffers GW, Johnson WH. McNarn NA (1936) Fatness, digestion and food of Passamaquoddy young herring. J Biol Bd Can 2:401-429

Batty RS, Blaxter JHS, Richard JM (1.990) Light intensity and the feeding behaviour of herring, Clupea harengus. Mar Biol 107:383-388

Bhattacharyya RN (1957) The food and feeding habits of larval and postlarval herring in the northern North Sea. Mar Res 3. Scottish Home Department, Edınburgh

Blaxter JHS (1964) Spectral sensitivity of the herring, Clupea harengus L. J exp Biol 41:155-162

Blaxter JHS (1980) Vision and the feeding of fishes. In: Bardach JE, Magnuson JJ, May RC, Reinhart JM (eds) Fish behavior and its use in the capture and culture of fishes. ICLARM Conf Proc 5:32-56

Blaxter JHS, Fuiman LA (1990) The role of the sensory systems of herring larvae in evading predatory fishes. J mar biol Ass UK 70:413-427

Blaxter JHS, Holliday FG (1958) Herring (Clupea harengus L.) in aquaria: II. Feeding. Mar Res 6. Scottısh Home Department, Edinburgh

Blaxter JHS, Jones MP (1967) The development of the retina and retinomotor responses in the herring. $\mathrm{J}$ mar biol Ass UK 47:677-697

Breder CM (1959) Studies on social groupings in fishes. Bull Am Mus nat Hist 117:393-482

Clarke WD (1963) Function of bioluminescence in mesopelagic organisms. Nature 198:1244-1246

Debus L, Mehner T. Thiel R (1992) Spatial and diel patterns of migration for Neomysis integer. In: Köhn J, Jones MB, Moffat A (eds) Taxonomy, biology and ecology of (Baltic) mysids (Mysidacea: Crustacea). Universitätsdruckerei der Universitat Rostock, p 79-82

Denton EJ, Nicol JAC (1965a) Studies on reflexion of light from silvery surfaces of fishes, with special reference to the bleak, Alburnus alburnus. J mar biol Ass UK 45: $683-703$

Denton EJ, Nicol JAC (1965b) Reflexion of light by external surfaces of the herring. Clupea harengus. J mar biol Ass UK 45:711-738

Denton EJ, Nicol JAC (1966) A survey of reflectivity in silvery teleosts. J mar biol Ass UK 46:685-722

Drenner RW, McComas SR (1980) The roles of zooplankter escape ability and fish size selectivity in the selective feeding and impact of planktivorous fish. In: Kerfoot WC (ed) Evolution and ecology of zooplankton communities. University Press of New England, Hanover, NH, p 587-593

Drenner RW. Strickler JR, O'Brien WJ (1978) Capture probability: the role of zooplankton escape in the selective feeding of planktivorous fish. J Fish Res Bd Can 35:1370-1373

Duntley SQ (1962) Underwater visibility. In: Hill MN (ed) The sea, Vol 1, Physical oceanography. Wiley, London, p $452-455$

Duntley SQ (1963) Light in the sea. J Opt Soc Am 53:214-233

Durbin AG, Durbin EG, Verity PG, Smayda TJ (1981) Voluntary swimming speeds and respiration rates of a filterfeeding planktivore, the Atlantic menhaden, Brevoortia tyrannus (Pisces: Clupeidae). Fish Bull US 78:877-886

Eggers DM (1977) The nature of prey selection by planktivorous fish. Ecology 58:46-59

Flinkman J, Vuonen I, Aro E (1988) Be visible, die fast: the predation strategy of Baltic herring. Int Counc Explor Sea Comm Meet (Baltic Fish Comm, Sess R, Poster) J:23
Gerritsen J, Strickler JR (1977) Encounter probabilities and community structure in zooplankton: a mathematical model. J Fish Res Bd Can 34:73-82

Gibson RN, Ezzi IA (1985) Effect of particle concentration on filter-and particulate-feeding in the herring Clupea harengus. Mar Biol 88:109-116

Gibson RN, Ezzi IA (1990) Relative umportance of prey size and concentration in determining the feeding behaviour of herring Clupea harengus. Mar Biol 107:357-362

GLOBEC (1989) Global ecosystem dynamics. EOS 70:82-85

Hastings JW (1971) Light to hide by: ventral luminescence to camouflage the silhouette. Science 173:1016-1017

Hester FJ (1968) Visual contrast thresholds of the goldfish (Carassius auratus). Vision Res 8:1315-1335

Janssen J (1981) Searching for zooplankton just outside Snell's window. Limnol Oceanogr 26:1168-1171

Janssen J (1982) Comparison of searching behavior for zooplankton in an obligate planktivore, blueback herring (Alosa aestivalis) and a facultative planktivore, bluegill (Lepomis machrochirus). Can J Fish Aquat Sci 39: $1649-1654$

Jerlov NG (1976) Marine optics. Elsevier oceanography series 14. Elsevier Scientific Publishing Company, Amsterdam

Johnson WH (1939a) Effects of light on movements of herring J Fish Res Bd Can 4:349-354

Johnson WH (1939b) Feeding of the herring. J Fish Res Bd Can 4:392-395

Kerfoot WC, Kellogg DL, Strickler JR (1980) Visual observations of live zooplankters: evasion, escape, and chemical defenses. In: Kerfoot EC (ed) Evolution and ecology of zooplankton communities. University of New England Press, Hanover, NH, p 10-27

Kettle D, O'Brien WJ (1978) Vulnerability of arctic zooplankton species to predation by small lake trout (Salvelinus namaycush). J Fish Res Bd Can 35:1495-1500

Kils U (1986) Verhaltensphysiologische Untersuchungen an pelagıschen Schwärmen - Schwarmbildung als Strategie zur Orientierung in Umwelt-Gradienten - Bedeutung der Schwarmbildung in der Aquakultur. Ber Inst Meeresk Kiel 163:1-172

Kils U (1992) The ecoSCOPE and dynIMAGE: microscale tools for in situ studies of predator-prey interactions. Arch Hydrobiol Beih Ergebn Limnol 36:83-96

Kislalioglu M, Gibson RN (1976) Some factors governing prey selection by the 15-spined stickleback, Spinachia spinachia (L.). J exp mar Biol Ecol 25:159-169

Loew ER, McFarland WN (1990) The underwater visual environment. In: Douglas RH, Djamgoz MBA (eds) The visual system of fish. Chapman \& Hall, London, p 1-43

Lythgoe JN (1971) Vision. In: Woods JD, Lythgoe JD (eds) Underwater science. An introduction to experiments by divers. Oxford University Press, London, p 103-139

Lythgoe JN (1979) The ecology of vision. Clarendon Press, Oxford

Mauchline J (1980) The biology of mysids and euphausiids Adv mar Biol 18:1-681

McFal.-Ngai MJ (1990) Crypsis in the pelagic environment. Am Zool 30:175-188

Munk O (1970) On the occurrence and significance of horizontal band-shaped retinal areae in teleosts. Vidensk Meddr dansk naturh Foren 133:85-120

Nicol JAC (1961) Some aspects of photoreception and vision in fishes. Adv mar Biol 1:171-208

O'Brien WJ (1979) The predator-prey interactions of planktivorous fish and zooplankton. Am Scient 67:572-581

Otterstrøm A (1910) Beobachtungen über die senkrechten Wanderungen des Mysisbestandes in der Ostsee bei Born- 
holm in den Sommermonaten 1906 und 1907. Meddr Komm Danm Fisk-Havunders (Ser Plankton) 1:1-12

Protasov VR (1968) Vision and near orientation of fish Izdatel'stvo Nauka Moskva. Israel program for scientific translations, Jerusalem (1970)

Rademacher K (1993) Angriffs- und Fluchtverhalten pelâgischer Fische (Spinachia spinachia) und ihrer Beute (Neomysis integer). Thesis, math-naturwiss Fak Kiel

Rosenthal H (1969) Untersuchungen über das Beutefangverhalten bei Larven des Herings Clupea harengus. Mar Biol 3:208-221

Rosenthal H, Hempel G (1970) Experimental studies in feeding and food requirements of herring larvae (Clupea harengus L.). In: Steele $J \mathrm{H}$ (ed) Marine food chains. Oliver \& Boyd, Edinburgh, p 344-364

Schnack D (1972) Nahrungsökologische Untersuchungen an Heringslarven. Ber dt wiss Kommn Meeresforsch 22 273-343

Stenson JAE (1980) Predation pressure from fish on two Chaoborus species as related to their visibility. In: Kerfoot WC (ed) Evolution and ecology of zooplankton communities. University Press of New England, Hanover, NH, p $618-622$

Strickler JR (1970) Über das Schwimmverhalten von Cyclo-

This article was submitted to the editor poiden bei Verminderungen der Bestrahlungsstärke. Schweiz Z Hydrol 32:150-180

Tamura $T$ (1957) A study of visual perception in fish, especially on resolving power and accommodation. Bull Jap Soc scient Fish 22:536-257

Tamura T, Wisby WJ (1963) The visual sense of pelagic fishes especially the visual axis and accomodation. Bull mar $\mathrm{Scl}$ Gulf Caribb 13:433-448

Thetmeyer H (1989) In-situ- und Labormessungen der optischen Eigenschaften pelagischer Organismen und deren Bedeutung für Beutefang- und Fluchtverhalten. Thesis, math-naturwiss Fak Kiel

Vinyard GL, O'Brien WJ (1976) Effects of light and turbidity on the reactive distance of bluegill (Lepomis macrochirus). J Fish Res Bd Can 33:2845-2849

Young RE, Roper CFE (1976) Bioluminescent countershading in midwater animals: evidence from living squids. Science 191:1046-1048

Zaret TM (1972) Predators, invisible prey and the nature of polymorphism in the Cladocera (class Crustacea). Limnol Oceanogr 17:171-184

Zaret TM, Kerfoot WC (1975) Fish predation on Bosmina longirostris: body-size selection versus visibility selection. Ecology 56:232-237

Manuscript first received: March 3, 1994

Revised version accepted: March 20, 1995 